\title{
Do Creativity and Intellectual Capital Matter for SMEs Sustainability? The Role of Competitive Advantage
}

\author{
Srikalimah SRIKALIMAH ${ }^{1}$, Ludi Wishnu WARDANA ${ }^{2}$, Diana AMBARWATI ${ }^{3}$, Ustadus SHOLIHIN ${ }^{4}$, \\ Rizky Arief SHOBIRIN ${ }^{5}$, Nuraidya FAJARIAH ${ }^{6}$, Agus WIBOWO $^{7}$
}

Received: September 01, 2020 Revised: October 26, 2020 Accepted: November 05, 2020

\begin{abstract}
SMEs as an organization to succeed and to be sustainable must have the most essential and strategic capital, namely creativity, competitive advantage, and intellectual capital. This study aims to explore how creativity and intellectual capital determines SMEs' sustainability as well as examine the emerging role of competitive advantage in supporting this relationship. A quantitative method was applied to gain a better understanding of the relationship between variables undergoing Structural Equation Modeling with Partial Least Square (SEM-PLS). This study collected data from 123 SMEs in East Java of Indonesia using an online survey. The approach adopted in this study is a convenience random sampling method, which is widely used in entrepreneurship and SMEs' sustainability research. The findings showed that intellectual capital positively affects both competitive advantage and SMEs' sustainability. Additionally, the result of this study confirms a robust relationship between intellectual capital and SMEs' sustainability. However, partially, creativity failed in explaining SMEs' sustainability. Furthermore, this study confirmed that competitive advantage has successfully mediated both the influence of creativity and intellectual capital to SMEs' sustainability. Although this research only involved participants in East Java, this study can be the first step for relevant research of SMEs' sustainability, in particular, in Indonesia.
\end{abstract}

Keywords: Creativity, Intellectual Capital, Competitive Advantage, SMEs Sustainability

JEL Classification Code: D80, D21, G20

${ }^{1}$ First Author and Corresponding Author. Department of Accounting, Faculty of Economics, Universitas Islam Kadiri, Indonesia [Postal Address: Jln. Sersan Suharmadji No. 38 Manisrenggo, Kota Kediri, Jawa Timur, 64128, Indonesia]

Email: srikalimah@uniska-kediri.ac.id

${ }^{2}$ Department of Business and Management Education, Faculty of Economics, Universitas Negeri Malang, Indonesia.

Email: ludi.wishnu.fe@um.ac.id

${ }^{3}$ Department of Management, Faculty of Economics, Universitas Islam Kadiri, Indonesia. Email: dianaambar88@gmail.com

${ }^{4}$ Department of Management, Faculty of Economics, Universitas Islam Kadiri, Indonesia. Email: tadus72@gmail.com

${ }^{5}$ Department of Chemistry, Faculty of Agriculture, Universitas Islam Kadiri, Indonesia. Email: rashobirin@gmail.com

${ }^{6}$ Department of Management, Faculty of Economics, Universitas Islam Kadiri, Indonesia. Email: aidyautomo@gmail.com

${ }^{7}$ Department of Economics Education, Faculty of Economics, Universitas Negeri Jakarta, Indonesia.

Email: agus-wibowo@unj.ac.id

(c) Copyright: The Author(s)

This is an Open Access article distributed under the terms of the Creative Commons Attribution Non-Commercial License (https://creativecommons.org/licenses/by-nc/4.0/) which permits unrestricted non-commercial use, distribution, and reproduction in any medium, provided the original work is properly cited.

\section{Introduction}

The coronavirus (Covid-19) has caused economic and public health shocks in various countries of the world (Bartik et al., 2020). As a result of Covid-19, company profits fell because their businesses could not be run effectively and investors incurred huge losses (Ozili \& Arun, 2020). The International Monetary Fund (IMF) predicts a bad global recession like the 2007-8 global financial crisis (Bartik et al., 2020).

Indonesia is also affected by Covid-19 (Nasution et al., 2020). There are three implications for Indonesia because of the Covid-19 pandemic, namely the tourism, trade, and investment sectors (Nasution et al., 2020). In the aspect of public consumption and purchasing power, this pandemic has caused many workers to decrease or even lose their income such that it affects the level of consumption and purchasing power of the community, especially those in the category of informal workers and daily workers (Nasution et al., 2020). Most people are conscientious about managing their financial expenses because of the uncertainty about 
when this pandemic will end (Hall et al., 2020). Covid-19 decreased people's purchasing power for consumer goods and put pressure on the producer and seller (Hall et al., 2020). In the corporate aspect, this pandemic has disrupted the performance of companies, especially those engaged in the trade, transportation, and tourism sectors (Hall et al., 2020).

The Covid-19 in Indonesia has also affected Small and Medium Enterprises (SMEs') in terms of total production, trade value, and the number of workers who have lost their jobs (Pakpahan, 2020; Styaningrum et al., 2020). Ministry of Cooperatives and Small and Medium Enterprises (Kemenkop UKM, 2018) stated that in 2018 there were $64,194,057$ SMEs' in Indonesia (or around 99 percent of the total business units) and employed 116,978,631 workers (97 percent of the total labor in the economic sector).

For SMEs to succeed in doing business must have the most essential and strategic capital, namely intellectual capital (Akhtar et al., 2015). The maximum use of intellectual capital will result in innovative solutions to reduce the consumption of other resources. The implementation of intellectual capital management in knowledge-based companies is through organizational structure, culture, and processes (Secundo et al., 2016). Developing nations such as Indonesia lacks the absorptive capacity to increase manufacturing activities from low-value-added activities to high-value-added activities (Akhtar et al., 2015). Due to the lack of appropriate skills among residents, local companies have not been able to fully exploit the abundance of knowledge or technology from foreign companies (Akhtar et al., 2015; Secundo et al., 2016).

Entrepreneurship and strategic management disciplines are inseparable, making it challenging to understand research findings in one area without simultaneously studying the results reported in other fields. Barney and Arikan (2001) suggested a close relationship, although not entirely determined, between the theories of competitive advantage, creativity, and entrepreneurship. Understanding the complementarity between entrepreneurship and strategic management provides a promising avenue for researchers examining how organizations create wealth. Although entrepreneurship and strategic management are concerned with wealth creation, their focus is slightly different. The research conducted by Barney et al. (2001) examined creativity and competitive advantage and did not examine the relationship between creativity and SMEs' sustainability.

The SMEs' owner mindset is about creativity, innovation, and taking opportunities that lead to the creation and success of organizational wealth and that this type of mindset enables entrepreneurs to make realistic decisions when faced with uncertainty (Wardana et al., 2010). Creativity is a way to unlock the entrepreneurial potential of individuals, entrepreneurs, and organizations because new ideas and approaches are the primary way to promote entrepreneurial culture (Bos-Brouwers, 2010; Chen, 2019). The research of Bontis et al. (2018) highlights that creativity is essential for organizational success. Likewise, Chen (2019), examining the importance of entrepreneurial quality among small business owners and non-business owners, also found creativity as one of the robust distinguishing characteristics. Therefore, encouraging creativity is a strategic choice that companies must consider because creativity creates a significant contribution to organizational innovation. Some of the previous studies conducted by Bos-Brouwers (2010) and Chen (2019) have discussed the relationship between creativity and SMEs sustainability without including intellectual capital and competitive advantage.

Furthermore, organizational value creation is primarily on intangible resources and capabilities, namely, intellectual capital (Inkinen, 2015). Edvinsson and Kivikas (2007) argue that intellectual assets are more important than tangible corporate value, and the World Bank (2005) reports that intangible assets account for 77 percent of total global wealth. Also, the sustainable ability of firms to compete in a modern knowledge economy stems increasingly from the exploitation of knowledge resources (Sharabati et al., 2010). As a result, intellectual capital is a combination of all knowledge and competencies that can manifest as a sustainable competitive advantage (Stewart, 2007).

Intellectual capital consists of information, intellectual property, intellectual material, knowledge, core techniques, customer relationships, and experiences that make a company rich (Stewart, 2007). Meanwhile, intellectual capital is about knowledge, applied experience, organizational technology, customer relations, and professional skills that make a company competitive in the market (Edvinsson \& Kivikas, 2007). Therefore, intellectual capital is not just a static intangible asset; on the contrary, it is a means to an end (Bontis et al., 2015). Stewart (2007) and Styaningrum et al. (2020) only examined the relationship between intellectual capital and competitive advantage without including the creativity variables.

Aldaba and Aldaba (2010) argue that SMEs' manufacturing sector gets large profits from skilled human resources, industrial and technological improvements or development of technology capabilities and companyspecific skills, enhancement of relationships between local firms through information exchange, capacity building, and adequate funding. A highly skilled and educated workforce gets a better position to adopt new technologies than a low-skilled workforce (Stone et al., 2015). The absorptive capacity of local companies is primarily determined by the company's R\&D capacity and employee education (Stone et al., 2015). Thus, the importance of SMEs' cannot be underestimated, and for them to develop and survive for a more extended period, they need robust intellectual capital. This research attempts to investigate the role of intellectual capital on the sustainability of SMEs in Indonesia (Akhtar et al., 2015). Meanwhile, the findings that have been done by Akhtar et al. (2015) and Secundo et al. (2016) discussed the relationship between intellectual capital and SMEs' 
sustainability without including the concepts of creativity and competitive advantage.

According to Porter (2003), competitive advantage is the heart of performance to meet competition. Competitive advantage as the profit strategy of companies collaborates to create more competitive advantages in their market. Competitive advantage ultimately grows from the value or benefits that the company can create for its buyers, more than the costs that the company must incur to make it (Daengs et al., 2019). Currently, the competitive situation is getting tougher; consumers are increasingly critical in deciding to buy a product or service (Aziz \& Samad, 2016). Competitive advantage will also be able to help improve the performance of SMEs (Styaningrum et al., 2020).

Based on a theoretical and empirical literature review, this study aims to analyze the influence of the business domain on competitive advantage and its effect on business performance in SMEs (Muñoz \& Kimmitt, 2019). Findings by Munoz \& Kimmitt (2019), Qosasi et al. (2019), and Daengs et al. (2019) only discussed the competitive advantage relationship with SMEs' sustainability without including intellectual capital and creativity. The finding of our study provides information related to the development of MSMEs and the importance of intellectual capital and creativity. The contribution of this study also fills in the gaps in previous research by examining the impact of intellectual capital, creativity, and competitive advantage on SMEs' sustainability.

\section{Literature Review}

\subsection{Creativity}

A developing organization and policy-making desperately need the concept of creativity, although at first, it is difficult to grasp and measure (Ward, 2004). In the 1990s, several studies showed that creativity is producing new ideas and marketable innovations (Chia \& Liang, 2016). Furthermore, Ward (2004) argues that creative activities can improve the performance of individuals, companies, and clusters. Florida (2002) argues that creativity, as another idea process seems useless or trivial. Creativity manifests in individuals who add to the economic value of a company (Florida, 2002).

Drazin et al. (1999) argue that the management perspective on creativity will be more real and treat it as the ability to identify and focus on more complex problems, to formulate propositions and make hypotheses, discuss ideas with others through socialization and networking, and even contradict expectations. As a result, creative people can choose to be involved (or not) in the creative process and to transfer creative ideas into marketable products (Kahn, 1990). Connecting new ideas and identifying problems can also benefit from creative activity, not just product creation. Several studies on performance outcomes treat creativity as homogeneous (Ward, 2004; Choi et al., 2009). The literature on creativity and entrepreneurship tends to regard creativity as a heterogeneous concept (Florida \& Mellander, 2009).

Based on this, we consider creativity as the individual's ability to introduce and apply new ideas and new work styles, which can differ across industries, known as creative industries (Ward, 2004). According to Florida and Mellander (2009), creativity embedded in an individual or industry is heterogeneous because it can vary by profession and industry, does not have to be qualifications, and spread through individual professional activities. Although members of the creative class are found in every industry, it is useful to distinguish workers employed in sectors that perform secondary creative tasks from workers employed in sectors that are the primary sector. It is also useful to distinguish creativity from human capital because what people do may differ from what they know (Marlet et al., 2004).

H1: Creativity has a positive impacton SMEs sustainability

H2: Creativity has a positive impact on competitive advantage

\subsection{Intellectual Capital}

Value creation from intellectual capital is a multidimensional concept of knowledge, experience, and practical capabilities (Campbell \& Abdul Rahman, 2010). Youndt et al. (2004) stated that to create value and extract value for organizations through knowledge, an intellectual model that contributes as a non-physical and non-monetary resource is needed. Meanwhile, knowledge store both individuals and company databases, business processes, systems, and relationships (Allameh, 2018).

Many researchers have carried out various studies about intellectual capital and its effects (Bontis et al., 2018; Henri et al., 2017). Intellectual capital has three main components, namely relational capital, human capital, and structural capital (Bontis et al., 2018; Henri et al., 2017).

One of the dimensions of intellectual capital is that it is the most essential and most intangible asset in organizations (Bontis, 1998). Human resource development pays close attention to education and training and career plans to increase employees' knowledge, skills, values, and social assets (Lepak \& Snell, 1999). Meanwhile, another aspect of intellectual capital is structural capital, as a non-human knowledge reserve in an organization that includes databases, organizational charts, process instructions, strategies, and anything that gives the organization more value than tangible assets (Bahrami et al., 2011).

Moreover, the need for a third dimension of intellectual capital, relational capital, refers to the number of assets that govern and manage relationships with the environment. These investments include the company's relationships with customers, shareholders, suppliers, competitors, government, public institutions, and the public (Allameh, 2018). 
H3: Intellectual capital has a positive impact on competitive advantage

H4: Intellectual capital has a positive impact on SMEs sustainability

\subsection{Competitive Advantage}

Competitive advantage reflects a company's ability to provide consumers with more excellent value, either by offering lower prices or by providing more benefits and services that justify higher prices (Berawi, 2004). Pavic et al. (2007) argue that competitive advantage is an essential factor for all industries. Therefore, an ambitious company must always pay attention to how to achieve and maintain a competitive advantage.

One area associated with a competitive advantage for SMEs is Information Technology (IT). The goal of IT is the survival of the company by using Internet technology to stay ahead of competitors and differentiate their position in the global market. Management companies often perceive IT as an opportunity to strengthen their organization's competitive advantage (Pavic et al., 2007). Many extant studies (Pavic et al., 2007) have focused on the relationship between IT adoption and competitive advantage. This study concludes that IT is a competitive weapon, and promoting IT as a resource enables organizations to gain a competitive advantage.

Furthermore, IT claims to gain competitive advantage, sustain, and promote these advantages (Porter, 1980). Internet commerce technology is one of the IT sub-disciplines. In their study of SMEs, Pavic et al. (2007) found that e-commerce helps SMEs create a competitive advantage. Also, in their study of manufacturing SMEs, Krell \& Matook (2009) found that information and communication technology (ICT) helps manufacturing companies maintain their competitive advantage by improving their reputation and quality of customer service, providing information feedback, lowering costs, and offering good coordination, efficient marketing skills, continuous development, relationships are good with distributors, suppliers, and customers, and assist with technical development. Therefore, ICT adoption and competitive advantage were found to have a healthy and positive relationship. Correspondingly, Krell and Matook (2009) studied the advantages of B2B e-commerce for SMEs' and found that increased productivity, improved product and service quality, sales growth, and increased revenue were considered the most significant advantages.

Competitive advantage and widespread adoption of ICT are encapsulated in the literature on cost, differentiation, growth, and quality. First, costing is passed as a competitive advantage stemming from B2B e-commerce adoption (Krell \& Matook, 2009). The latter use reduced the cost of communicating with business partners (for example, fax, mail, and telephone charges). Inventory costs are another example given by Lumpkin et al. (2002). Technology services reduce the costs of marketing, advertising, and product sales and sales (Teo \& Pian, 2003).

Likewise, Krell \& Matook (2009) showed that customer support costs could be reduced by Internet technology and business operating costs. Travel trips are another type of cost caused by technology adoption (Krell \& Matook, 2009). Teo and Pian (2003), found that SMEs can pay their document costs (e.g., document storage and manipulation costs) and document publication costs (e.g., catalog and brochure publication costs) through the adoption of the Internet technology. Second, differentiation refers to increasing the credibility and prestige of the organization. Providing new products and services to customers is one way to differentiate a company (Teo \& Pian, 2003). Krell \& Matook (2009) found that brand enhancement differentiates firms from discrimination. Third, proper growth can also mean it is vital to increase the organization's market, grow sales, and organizational income, or increase customer satisfaction (Teo \& Pian, 2003). Fourth, quality is one of the components of competitive advantage achieved using administrative areas, such as product and service quality, information quality, and quality of relationships with business partners (Krell \& Matook, 2009), customer service quality (for example, quick responses. to customer inquiries, immediate follow up on customer claims and complaints), and transaction errors (Lai et al., 2006).

H5: Competitive advantage has a positive impact on SMEs Sustainability

H6: Competitive advantage mediates the influence of creativity and SMEs Sustainability

H7: Competitive advantage mediates the influence of Intellectual capital and SMEs Sustainability

\subsection{SMEs' Sustainability}

Sustainability can be defined as qualities that help serve, save, and maintain and have three widely accepted components: the environment, society, and the economy (Ciceri et al., 2010). Sustainability can help organizations gain a competitive advantage (Preuss, 2007). Kleindorfer \& Singhal (2005) asserts that the practice of sustainable operations management (SOM) has a positive impact on an organization's economic performance and supports it to minimize adverse impacts on society and the environment. According to Gotschol et al. (2014) and Suparno et al. (2019), internal environmental programs in organizations have a positive impact on the economic, environmental, and social performance of the organization because every investment in an environmental management program helps to gain economic benefits for the company in the long run. 
Organizations should consider the term 'green' as a means to achieve a competitive advantage to go global and to increase market share because today's highly educated and highly conscious customers prefer environmentally friendly products (Gotschol et al., 2014). Social sustainability practices help organizations achieve a more significant social reputation. Sustainability in this business requires entrepreneurial intentions to start a business.

\section{Research Methods and Materials}

\subsection{Study Design}

This study used a quantitative research method to acquire a detailed understanding of how creativity and intellectual capital can affect SMEs' sustainability as well as understanding the mediating role of competitive advantage (see figure 1).

The approach adopted in this study is a convenience random sampling method, which is widely used in entrepreneurship and SMEs' sustainability research. In total, approximately 130 SME owners have participated in this quantitative research. After the validation process, we found that about seven questionnaires were returned incomplete. However, 123 questionnaires proved useful for further analysis. Participants were chosen from several SMEs' in East Java in Indonesia through an online survey. The demographics respondents were male instead of females, with 65 percent and 35 percent, respectively (see Table 1).

\subsection{Measurement Development}

The first few questions were designed to measure creativity by adapting eight indicators from Amabile (2017). To measure SMEs' sustainability, we adapted three indicators from Urban \& Naidoo (2012). The intellectual capital was explained by 18 indicators from Jain et al. (2017) and
Sharabati et al. (2010). Lastly, to understand the competitive advantage, we applied five indicators from Aboelmaged (2018), Jain et al. (2017), and Mahmood and Hanafi (2013 Participants were asked to respond using a 5-point Likert scale ranging from 1, indicating "strongly disagree" to 5 indicating "strongly agree." The data analysis technique in this study used Structural Equation Modeling Partial Least Squares (SEM-PLS) with SmartPls 3.0 software tools.

\section{Results and Discussion}

\subsection{Assessment of Outer Model}

The first step of outer model assessment in PLS analysis is to ensure that it is reliable. A score of $0.6-0.8$ indicates good construct reliability (Hair et al., 2014). For validity analysis, construct validity is applied since it is more relevant (Cronbach, 1995). Two sorts of validity tests were performed, convergent validity and discriminant validity. Convergent validity is the extent to which a measure positively correlates with another measure of the same construct. In examining the convergent validity of a measure in PLS, the average variance extracted (AVE) and item loadings are evaluated (Hair et al., 2013). An AVE value higher than 0.50 indicates that, on average, the construct explained more than half of its indicator variance. As such, the rule of thumb is that an AVE value greater or equal to 0.50 is acceptable (Hair et al., 2013).

As shown in Table 1, the values of CR for each construct range from 0.91-0.97 which exceed 0.6-0.7 as a cut-off score, so the construct reliability is achieved. The convergence validity test results in some indicators (ic1, ic6, ic7, ic8, ic9, ic10, and ic11) which should be removed due to the items loading lower than 0.7. After the elimination, all the items are loading higher than 0.6 and the value of AVE for each construct ranges from $0.65-0.83$, which exceeds the recommended value 0.5 . Thus the convergence validity is achieved.

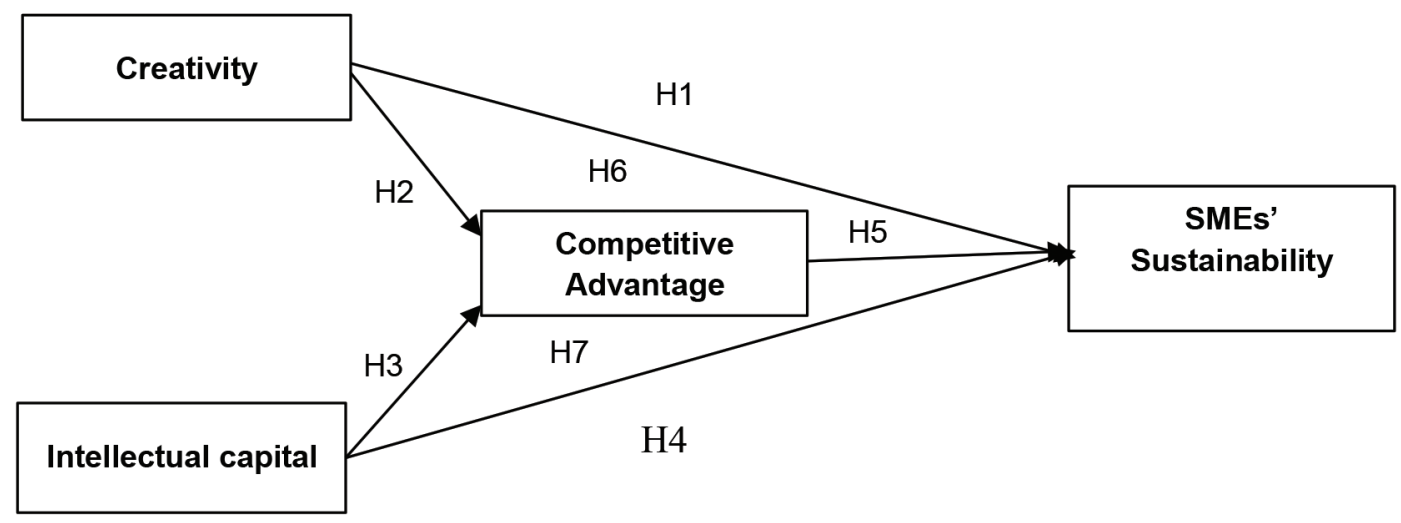

Figure 1: Theoretical Framework 
Table 1: The demographic of respondents

\begin{tabular}{|c|c|c|c|}
\hline S/No. & Characteristics & Frequency & Percentage \\
\hline \multirow[t]{3}{*}{1.} & Gender & & \\
\hline & Female & 43 & 35 \\
\hline & Male & 80 & 65 \\
\hline \multirow[t]{4}{*}{2.} & Business area & & \\
\hline & Restaurant & 59 & 48 \\
\hline & Service & 44 & 36 \\
\hline & Fashion & 20 & 16 \\
\hline \multirow[t]{6}{*}{3.} & No of years in the current company & & \\
\hline & $>10$ years & 29 & 24 \\
\hline & $7-9$ years & 18 & 15 \\
\hline & 4-6 years & 29 & 24 \\
\hline & $1-3$ years & 29 & 24 \\
\hline & $<2$ years & 18 & 15 \\
\hline \multirow[t]{6}{*}{4.} & Educational Background & & \\
\hline & Senior High School & 61 & 50 \\
\hline & Diploma & 13 & 11 \\
\hline & Bachelor degree & 33 & 27 \\
\hline & Postgraduate degree & 9 & 7 \\
\hline & Certificate level & 7 & 6 \\
\hline \multirow[t]{4}{*}{5.} & No. of employees & & \\
\hline & $1-4$ & 94 & 76 \\
\hline & $5-19$ & 26 & 21 \\
\hline & $20-99$ & 3 & 2 \\
\hline \multirow[t]{5}{*}{6.} & Revenue per year & & \\
\hline & $\leq 100$ Million & 81 & 66 \\
\hline & > 100 juta-Rp200 Million & 25 & 20 \\
\hline & > 200 juta-Rp300 Million & 15 & 12 \\
\hline & $>300$ Million & 2 & 2 \\
\hline
\end{tabular}

Table 2 shows the discriminant validity test in which items differ among constructs or measure distinct concepts. The AVE for each component should be greater than the squares of the correlation between the component and all other components (Fitch et al., 2005). On the other hand, the research model is considered to have a good discriminant when the correlation among the components is lower than the square root of the AVE (Fornell \& Larcker, 1981).

\subsection{Assessment of Structural Model}

All the data was run using 500 bootstrapped samples, through 123 cases. The Variance Inflation Factor (VIF) coefficient is higher than 5.00 (Hair et al., 2014). The test results showed that the range of inner VIF is within 1.253 2.324 . Therefore, there is no collinearity problem.

\subsubsection{Path Coefficient}

We use the path coefficients to evaluate the structural models. The t-statistics was estimated using the bootstrap resampling procedure. According to Hair et al. (2013), the bootstrapping procedure is a non-parametric approach for estimating the precision of the PLS-SEM estimates. In this study, we ran all the data using 500 bootstrapped samples. As shown in Table 3, all of the hypotheses were significant since the range of $\mathrm{p}$-value for each relationship is within $0.00-0.033$, less than 0.05 (see Figure 2). 
Table 2: Results of Measurement (Outer) Model

\begin{tabular}{|c|c|c|c|c|c|}
\hline Construct & Item & Loading & CR & Cronbach Alpha & AVE \\
\hline \multirow[t]{3}{*}{ SMEs Sustainability (SS) } & ss1 & 0.86 & \multirow[t]{3}{*}{0.93} & \multirow[t]{3}{*}{0.89} & \multirow[t]{3}{*}{0.83} \\
\hline & ss2 & 0.95 & & & \\
\hline & ss3 & 0.91 & & & \\
\hline \multirow[t]{10}{*}{ Intellectual capital (IC) } & ic12 & 0.81 & \multirow[t]{10}{*}{0.95} & \multirow[t]{10}{*}{0.94} & \multirow[t]{10}{*}{0.65} \\
\hline & ic13 & 0.85 & & & \\
\hline & ic14 & 0.78 & & & \\
\hline & ic15 & 0.80 & & & \\
\hline & ic16 & 0.84 & & & \\
\hline & ic17 & 0.84 & & & \\
\hline & ic2 & 0.70 & & & \\
\hline & ic3 & 0.75 & & & \\
\hline & ic4 & 0.83 & & & \\
\hline & ic5 & 0.82 & & & \\
\hline \multirow[t]{5}{*}{ Competitive Advantage (CA) } & ca1 & 0.75 & \multirow[t]{5}{*}{0.91} & \multirow[t]{5}{*}{0.89} & \multirow[t]{5}{*}{0.69} \\
\hline & $\mathrm{ca} 2$ & 0.85 & & & \\
\hline & ca3 & 0.84 & & & \\
\hline & ca4 & 0.88 & & & \\
\hline & ca5 & 0.81 & & & \\
\hline \multirow[t]{8}{*}{ Creativity $(\mathrm{C})$} & $\mathrm{c} 1$ & 0.89 & \multirow[t]{8}{*}{0.97} & \multirow[t]{8}{*}{0.96} & \multirow[t]{8}{*}{0.81} \\
\hline & c2 & 0.93 & & & \\
\hline & c3 & 0.92 & & & \\
\hline & c4 & 0.89 & & & \\
\hline & c5 & 0.90 & & & \\
\hline & c6 & 0.91 & & & \\
\hline & c7 & 0.87 & & & \\
\hline & c8 & 0.89 & & & \\
\hline
\end{tabular}

Table 2: Discriminant Validity

\begin{tabular}{|c|c|c|c|c|}
\hline & C & CA & IC & SS \\
\hline Creativity $(\mathrm{C})$ & 0.90 & & & \\
\hline Competitive Advantage (CA) & 0.85 & 0.834 & & \\
\hline Intellectual capital (IC) & 0.75 & 0.760 & 0.80 & \\
\hline SMEs Sustainability (SS) & 0.57 & 0.65 & 0.67 & 0.91 \\
\hline
\end{tabular}

Table 3: Path Coefficients and Results of Hypotheses Testing

\begin{tabular}{|c|c|c|c|c|c|}
\hline Hypotheses & Relationship & Beta & T-value & P-values & Decision \\
\hline $\mathrm{H} 1$ & $\mathrm{C} \rightarrow \mathrm{SS}$ & -0.13 & 0.97 & 0.33 & Rejected \\
\hline $\mathrm{H} 2$ & $\mathrm{C} \rightarrow \mathrm{CA}$ & 0.65 & 11.44 & 0.00 & Accepted \\
\hline $\mathrm{H} 3$ & $\mathrm{IC} \rightarrow \mathrm{CA}$ & 0.26 & 4.12 & 0.00 & Accepted \\
\hline $\mathrm{H} 4$ & $\mathrm{IC} \rightarrow \mathrm{SS}$ & 0.46 & 5.26 & 0.00 & Accepted \\
\hline $\mathrm{H} 5$ & $\mathrm{CA} \rightarrow \mathrm{SS}$ & 0.42 & 3.06 & 0.00 & Accepted \\
\hline $\mathrm{H} 6$ & \multicolumn{2}{|l|}{$\mathrm{C} \rightarrow \mathrm{CA} \rightarrow \mathrm{SS}$} & 2.95 & 0.00 & Accepted \\
\hline $\mathrm{H} 7$ & \multicolumn{2}{|l|}{$\mathrm{IC} \rightarrow \mathrm{CA} \rightarrow \mathrm{SS}$} & 2.45 & 0.01 & Accepted \\
\hline
\end{tabular}




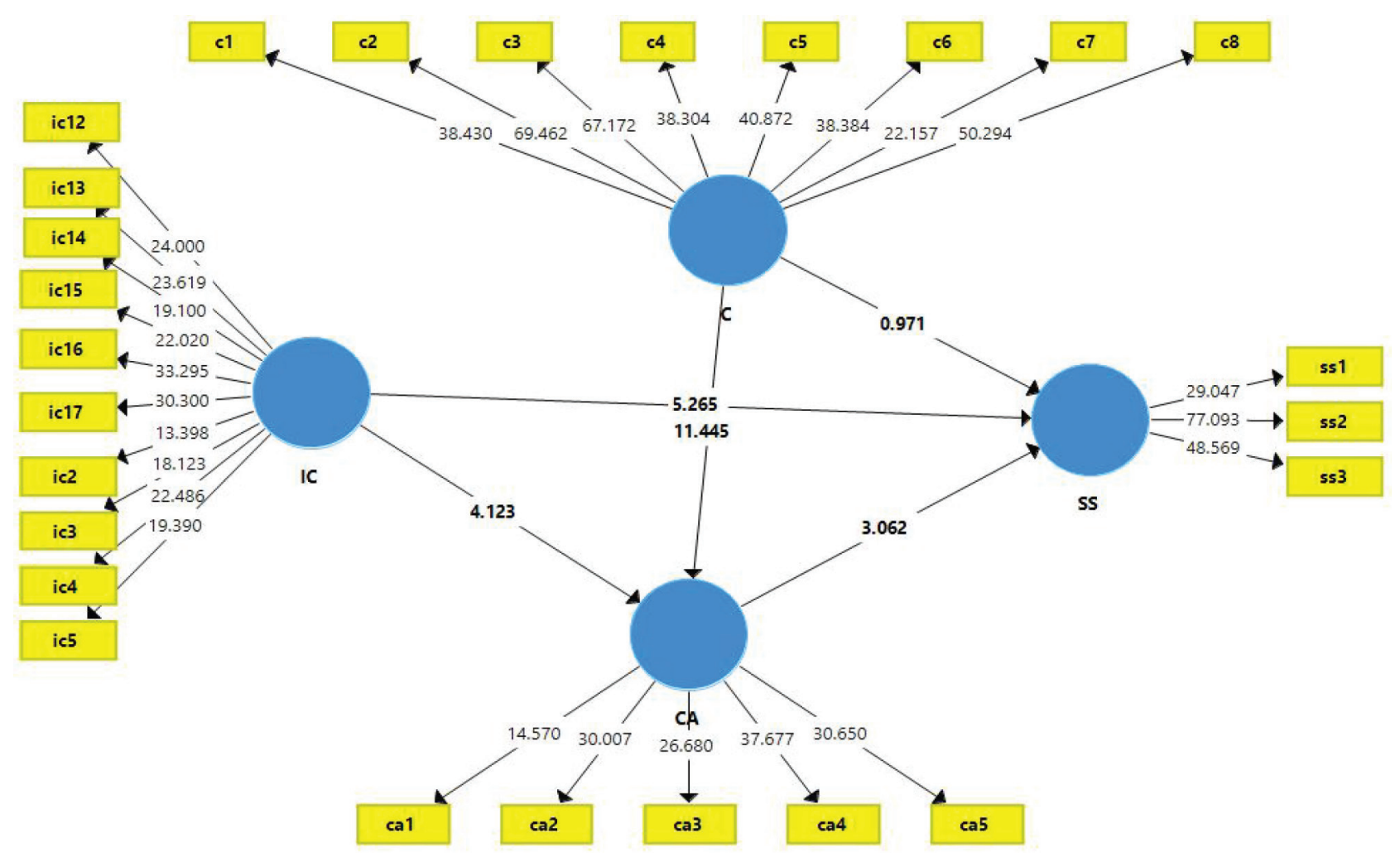

Figure 2: Measurement and structural model estimation

\subsubsection{Model Fit}

According to Hair et al. (2014), model R-square indicates the model's predictive accuracy. R-square values falling on or greater than 0.75 are considered as substantial, those that fall on 0.50 are considered moderate, and those that are 0.25 are considered as weak (Hair et al., 2014). The results show that IC and C explain the 76.2 percent variances of CA, a substantial level of predictivity. Furthermore, C, IC, and CA explain $51.2 \%$ variance of SS, a moderate level of predictivity. In addition to evaluating the $\mathrm{R} 2$ value, the $\mathrm{f} 2$ effect size test was employed. The assessment of the effect size $\mathrm{f} 2$ seeks to evaluate whether exogenous constructs have a substantive impact on endogenous constructs. Based on the guidelines provided by Hair et al. (2014), f2 values of $0.02,0.15$, and 0.35 respectively represent the small, medium, and large effect of the exogenous constructs on the endogenous constructs. The range of $\mathrm{f} 2$ is between 0.263-0.898. Specifically, the effect size of C and IC on $\mathrm{CA}$ was a large effect (f2 value is 0.898 ). However, the effect size of C, IC, and CA on SS was medium level (f2 value is 0.263 ).

The results of this study answered seven hypotheses. The first hypothesis confirms that there is a direct positive impact of creativity on SMEs' sustainability. The results of the study found that $\mathrm{H} 1$ was not a significant $\mathrm{P}$-value of 0.33 . This result means that creativity does not affect SMEs' sustainability. In this condition, participants who have participated in this research for creativity do not affect the sustainability of their business. The results of this study do not support the findings of Akhtar et al. (2015) and Jain et al. (2005). Creativity currently lacks positive appreciation in the company, where the sustainability of the business is not a definite guarantee in the future.

The second hypothesis confirms that there is a direct positive impact between creativity and competitive advantage. The results of the study found that $\mathrm{H} 2$ was a significant $\mathrm{P}$-value of 0.00 . This result means that creativity affects competitive advantage. The results of this study support several studies by Akhtar et al. (2015), BosBrouwers (2010), Amabile (2017, Chen (2019), and Jain et al. (2005) who stated that creativity has a positive effect on SMEs sustainability. Currently, SMEs have used new ways to achieve goals and objectives in their business. With new ideas and practical support with Information Technology (IT), SMEs will improve the performance and sales of their business (Bos-Brouwers, 2010). They will come up with new ways to improve the quality of their business (Chen, 2019). With the conditions of this pandemic, Covid-19, good creative ideas can increase the current SMEs' business. 
With the development of IT, these SMEs' have started to use new ways of carrying out their production (Kanama, 2017). By having references from IT, they have creative solutions for various problems in the production process; this will make the sustainability of the SME business even longer (Styaningrum et al., 2020; Srikalimah et al., 2020). These SMEs also develop adequate plans and schedules to implement new ideas (Srikalimah et al., 2020). They always show their creativity in the tasks given. This creativity also has an impact on the competitive advantage, which is supported by the results of the research conducted by Berawi (2004) and Styaningrum et al. (2020), who found that currently, the acquisition of raw materials at lower prices can be obtained from the creativity to get information from IT. The participants in this study can also offer various types of products with the creativity they produce and IT. They also have unique products that are difficult for competitors to imitate. With IT, SMEs can improve the right image before its customers (Ramdhani et al., 2017).

Meanwhile, the third and fourth hypotheses confirm a direct positive impact between intellectual capital on competitive advantage and SMEs' sustainability. The results of the study found that $\mathrm{H} 3$ and $\mathrm{H} 4$ are significant $\mathrm{p}$-values of 0.00 . This result means that intellectual capital affects competitive advantage and SMEs' sustainability. The results of this study support several studies that have been conducted by Inkinen (2015), Sharabati et al. (2010), Bahrami et al. (2011), Henri et al. (2017), Akhtar et al. (2015) who stated that intellectual capital has a positive effect on competitive advantage and SMEs' sustainability. Currently, employers know that they have employees who have sufficient and appropriate experience to carry out their duties. Employees receive regular training programs, and they also have innovative ideas to increase company profits. Employees are also very competent in carrying out work. Moreover, employee turnover in the company is relatively low for the last two years (Sharabati et al., 2010).

The SMEs' who were the participants of this study had well-documented systems and procedures. They also have systems and procedures that support innovation. SMEs currently use computer services and information technology for communication, coordination, and information distribution. The SMEs' recruitment program is comprehensive in recruiting the best prospective employees (Sharabati et al., 2010). The SMEs obtain much valuable information about market needs and trends from customer data. The SMEs quickly resolves customer problems. They also take advantage of the wants and needs of the customer by continually trying to keep the customer satisfied. Currently, the company works together with suppliers to develop and improve product quality (Sharabati et al., 2010).

Furthermore, the fifth hypothesis confirms a direct positive impact between competitive advantages on SMEs' sustainability. The results of the study found that $\mathrm{H} 5$ is a significant $P$ value of 0.00 . This result means that competitive advantage affects SMEs' sustainability. The results of this study support several studies by Ciceri et al. (2010), Aziz \& Samad (2016), Munoz \& Kimmitt (2019), Qosasi et al. (2019), and Aboelmaged (2018) who stated that competitive advantage has a positive effect on SMEs' sustainability. Currently, SMEs' have obtained raw materials at a lower price and can offer various products. The company has a product that has a unique product design and is difficult for competitors to imitate. The company also has the right image before customers.

The sixth hypothesis confirms that there is an indirect positive impact between creativity on SMEs' sustainability through competitive advantage. The results of the study found that $\mathrm{H} 6$ was a significant $\mathrm{p}$-value of 0.00 . This result means that creativity has an indirect positive impact on SMEs' sustainability through competitive advantage. The results of this study support several studies by Mamun et al. (2017), Amabile (2017), and Styaningrum et al. (2020), that with creativity and entrepreneurship and the existence of several advantages obtained, SMEs' sustainability can be achieved by increasing employment, sales turnover, and profits over the last two years.

The last hypothesis confirms an indirect positive impact between intellectual capital on SMEs' sustainability through competitive advantage. The results of the study found that $\mathrm{H} 7$ was a significant p-value of 0.01 . This means that intellectual capital has an indirect positive impact on SMEs' sustainability through competitive advantage. The results of this study support several studies by Allameh (2018) and Styaningrum et al. (2020) that with intellectual capital and entrepreneurship, and the existence of several advantages, SMEs' sustainability can be achieved by increasing employment, sales turnover, and profits over the last two years (Styaningrum et al., 2020).

\section{Conclusions}

This paper aims to explore how creativity and intellectual capital determines SMEs' sustainability as well as examine the emerging role of competitive advantage in supporting this relationship. The findings showed that intellectual capital positively affects both competitive advantage and SMEs' sustainability. Additionally, the result of this study confirms a robust relationship between intellectual capital and SMEs' sustainability. However, partially, creativity failed in explaining SMEs' sustainability. Lastly, this study confirmed that competitive advantage has successfully mediated both the influence of creativity and intellectual capital to SMEs' Sustainability.

Creativity does not have a significant effect on SMEs' competitive advantage, which means that creativity needs to 
be robust to gain a competitive advantage and the SMEs' sustainability. The need to create new ways and ideas to improve performance. First, universities around UKM need to conduct comprehensive training and mentoring for SMEs' entrepreneurs with IT support to promote and carry out efficiency and product differentiation. Second, the information and communication office can create a digital platform for access to SMEs' information and promotions. Third, the Trade and Industry Office can assist in tools, materials, and practical training in effective and efficient production processes.

The limitation of this research is that it only involves participants in East Java; future research should involve SMEs throughout Indonesia to find their characteristics and uniqueness in sustainability. Nevertheless, this study can be the first step for relevant research of SMEs' sustainability, in particular, Indonesia.

\section{References}

Aboelmaged, M. (2018). The drivers of sustainable manufacturing practices in Egyptian SMEs and their impact on competitive capabilities: A PLS-SEM model. Journal of Cleaner Production, 175, 207-221. https://doi.org/10.1016/j.jclepro.2017.12.053

Akhtar, C. S., Ismail, K., Ndaliman, M. A., Hussain, J., \& Haider, M. (2015). Can intellectual capital of SMEs help in their sustainability efforts. Journal of Management Research, 7(2), 82. https://doi.org/10.5296/jmr.v7i2.6930

Aldaba, R. M., \& Aldaba, F. T. (2010). Assessing the spillover effects of FDI to the Philippines. PIDS Discussion Paper Series 27.

Allameh, S. M. (2018). Antecedents and consequences of intellectual capital: The role of social capital, knowledge sharing and innovation. Journal of Intellectual Capital, 19(5), 858-874. https://doi.org/10.1108/JIC-05-2017-0068

Amabile, T. M. (2017). In pursuit of everyday creativity. The Journal of Creative Behavior, 51(4), 335-337. doi:10.1002/ jocb. 200

Aziz, N. N. A., \& Samad, S. (2016). Innovation and competitive advantage: Moderating effects of firm age in foods manufacturing SMEs in Malaysia. Procedia Economics and Finance, 35(October 2015), 256-266. https://doi.org/10.1016/ s2212-5671(16)00032-0

Bahrami, S., Rajaeepour, S., Aghahosseni, T., Bakhtiar Nasrabadi, H. A., \& Yarmohamadian, M. H. (2011). Analysis of multiple relationships of intellectual capital and organizational innovation in higher education. Quarterly Journal of Research and Planning in Higher Education, 17(3), 27-50.

Barney, J. B., \& Arikan, A. M. (2001). The resource-based view: Origins and implications. In: The Blackwell handbook of strategic management. Oxford, UK: Blackwell Publishers

Bartik, A. W., Bertrand, M., Cullen, Z., Glaeser, E. L., Luca, M., \& Stanton, C. (2020). The impact of COVID-19 on small business outcomes and expectations. Proceedings of the National Academy of Sciences of the United States of America, 117(30), 17656-17666. https://doi.org/10.1073/pnas.2006991117

Berawi, M. A. (2004). Quality revolution: Leading the innovation and competitive advantages. International Journal of Quality and Reliability Management, 21(4), 425-438. https://doi. org/10.1108/02656710410530118

Bontis, N., Ciambotti, M., Palazzi, F., \& Sgro, F. (2018). Intellectual capital and financial performance in social cooperative enterprises. Journal of Intellectual Capital, 19(4), 712-731. https://doi.org/10.1108/JIC-03-2017-0049

Bontis, N., Janosevic, S., \& Dženopoljac, V. (2015). Intellectual capital in Serbia's hotel industry. International Journal of Contemporary Hospitality Management, 27(6), 1365-1384. https://doi.org/10.1108/IJCHM-12-2013-0541

Bos-Brouwers, H. E. J. (2010). Corporate sustainability and innovation in SMEs: Evidence of themes and activities in practice. Business Strategy and the Environment, 19(7), 417435. https://doi.org/10.1002/bse.652

Campbell, D., \& Abdul Rahman, M. R. (2010). A longitudinal examination of intellectual capital reporting in Marks \& Spencer annual reports, 1978-2008. British Accounting Review, 42(1), 56-70. https://doi.org/10.1016/j.bar.2009.11.001

Chen, M. (2019). Entrepreneurial marketing as a way for Chinese SMEs to operate effectively in a transition economy. Global Research Symposium on Marketing and Entrepreneurship, June 27-29, 2019. Regent's University, London, UK.

Ciceri, N. D., Garetti, M., \& Sperandio, S. (2010). From product end-of-life sustainable considerations to design management. IFIP Advances in Information and Communication Technology, 338 AICT (pp.152-159). Springer. https://doi.org/10.1007/9783-642-16358-6_20

Daengs G. S, A., Kurniasih, N., Reni, A., Istanti, E., Zuhroh, D., \& Qomariah, N. (2019). The effect of business sphere on competitive advantage and business performance of SMEs. Management Science Letters, 9(8), 1153-1160. https://doi. org/10.5267/j.msl.2019.4.025

Depkop. (2018). Development of data on micro, small, medium and large enterprises. Retrieved fron www.Depkop.Go.Id.

Edvinsson, L., \& Kivikas, M. (2007). Intellectual capital (IC) or Wissensbilanz process: Some German experiences. Journal of Intellectual Capital, 8(3), 376-385. https://doi. org/10.1108/14691930710774821

Florida, R. (2002). The rise of the creative class. Why cities without gays and rock bands are losing the economic development race. Washington Monthly, 3(May), 1-12.

Florida, R., \& Mellander, C. (2009). There goes the metro: How and why bohemians, artists and gays affect regional housing values. Journal of Economic Geography, 10(2), 167-188. https://doi. org/10.1093/jeg/lbp022

Gotschol, A., De Giovanni, P., \& Esposito Vinzi, V. (2014). Is environmental management an economically sustainable 
business? Journal of Environmental Management, 144, 73-82. https://doi.org/10.1016/j.jenvman.2014.05.001

Hall, C. M., Scott, D., \& Gossling, S. (2020). Pandemics, transformations and tourism: Be careful what you wish for. Tourism Geographies, 22(3), 577-598. https://doi.org/10.1080/ 14616688.2020.1759131

Han, Y., \& Li, D. (2015). Effects of intellectual capital on innovative performance: The role of knowledge-based dynamic capability management decision, 53(1), 40-56. https://doi.org/10.1108/ MD-08-2013-0411. Management Decision, 53(1), 40-56.

Henri, H., Paavo, R., Mika, V., \& Aino, K. (2017). Intellectual capital, knowledge management practices and firm performance. Journal of Intellectual Capital, 18(4), 904-922. https://doi.org/http://dx.doi.org/10.1108/MRR-09-2015-0216

Inkinen, H. (2015). Review of empirical research on intellectual capital and firm performance. Journal of Intellectual Capital, 16(3), 518-565. https://doi.org/10.1108/jic-01-2015-0002

Jain, P., Vyas, V., \& Roy, A. (2005). Social responsibility. Social Responsibility Journal, 13(1), 1-23. https://doi.org/10.1108/ SRJ-04-2015-0048

Kahn,W.A.(1990). Psychological conditions of personal engagement and disengagement at work. Academy of Management Journal, 33(4), 692-724. https://doi.org/10.2307/256287

Kanama, D. (2017). Digital transformation in smart manufacturing: Manufacturing transformation toward mass customization and personalization in the traditional food industry. Intech .

Kleindorfer, P., Singhal, K. W. L. (2005). Production and operations management. Sustainable Operations Management, 14(4), 482-492. https://doi.org/10.1007/978-3-319-14002-5

Krell, K., \& Matook, S. (2009). Competitive advantage from mandatory investments: An empirical study of Australian firms. Journal of Strategic Information Systems, 18(1), 31-45. https://doi.org/10.1016/j.jsis.2008.12.001

Lai, F., Zhao, X., \& Wang, Q. (2006). The impact of information technology on the competitive advantage of logistics firms in China. Industrial Management and Data Systems, 106(9), 1249-1271. https://doi.org/10.1108/02635570610712564

Lepak, D. P., \& Snell, S. A. (1999). The human resource architecture: Toward a theory of human capital allocation and development. Academy of Management Review, 24(1), 31-48. https://doi. org/10.5465/AMR.1999.1580439

Mamun, A. A., Nawi, N. B. C., Mohiuddin, M., Shamsudin, S. F. F. B., \& Fazal, S. A. (2017). Entrepreneurial intention and startup preparation: A study among business students in Malaysia. Journal of Education for Business, 92(6). https://doi.org/10.1 080/08832323.2017.1365682

Muñoz, P., \& Kimmitt, J. (2019). Social mission as competitive advantage: A configurational analysis of the strategic conditions of social entrepreneurship. Journal of Business Research, 101(November), 854-861. https://doi.org/10.1016/j. jbusres.2018.11.044
Nasution, D. A. D., Erlina, E., \& Muda, I. (2020). The impact of Covid-19 pandemic on the Indonesian economy. Jurnal Benefita, 5(2), 212. https://doi.org/10.22216/jbe.v5i2.5313

Ozili, P. K., \& Arun, T. (2020). Spillover of COVID-19: Impact on the global economy. Working Paper MPRA No. 99850. Germany: University Library of Munich. https:/doi. org/10.2139/ssrn.3562570

Pakpahan, A. K. (2020). Covid-19 implications for micro, small, and medium enterprises. Jurnal Ilmiah Hubungan Internasional, 1(1), 59-64. https://doi.org/10.26593/jihi.v0i0.3870.59-64

Pavic, S., Koh, S. C. ., Simpson, M., \& Padmore, J. (2007). Could e-business create a competitive advantage in UK SMEs? Benchmarking: An International Journal, 14(3), 320-351. https://doi.org/10.1108/14635770710753112

Porter. (1980). Corporate strategy. Hoboken, NJ: Wiley.

Porter, M. E. (2003). The economic performance of regions. Regional Studies, 37(6-7), 545-546. https://doi. org/10.1080/0034340032000108688

Preuss, L. (2007). Buying into our future: Sustainability initiatives in local government procurement. Business Strategy and the Environment, 16(5), 354-365. https://doi.org/10.1002/bse.578

Qosasi, A., Permana, E., Muftiadi, A., Purnomo, M., \& Maulina, E. (2019). Building SMEs' competitive advantage and the organizational agility of apparel retailers in indonesia: The role of ICT as an initial trigger. Gadjah Mada International Journal of Business, 21(1), 69-90. https://doi.org/10.22146/ gamaijb.39001

Ramdhani, M. A., Aulawi, H., Ikhwana, A., \& Mauluddin, Y. (2017). Model of green technology adaptation in small and medium-sized tannery industry. Journal of Engineering and Applied Sciences, 12(4), 954-962. https://doi.org/10.3923/ jeasci.2017.954.962

Srikalimah, S., Wardana, L., Ambarwati, D., \& Sholihin, U. (2020). Preliminary observation study of Kampung Tahu in Tinalan Village, Kediri City, for implementation of educational tourism village concept based on industrial centers. KnE Social Sciences, 2020, 51-65. https://doi.org/10.18502/kss.v4i7.6842

Stewart, T. A. (2007). The wealth of knowledge: Intellectual capital and the twenty-first century organization. New York, NY: Crown Business.

Stone, S., Mikic, M., Agyeben, M., Anukoonwattaka, W., Duval, Y., Heal, A., \& Huang, F. (2015). Asia-Pacific trade and investment report 2015: Supporting participation in value Chains. Thailand: UN Publications

Styaningrum, F., Soetjipto, B. E., \& Wulandari, D. (2020). The determinants of SMEs' sustainability. Humanities \& Social Sciences Reviews, 8(4), 422-430. https://doi.org/10.18510/ hssr.2020.8441

Suparno, S., Wibowo, A., Mukhtar, S., Narmaditya, B. S., \& Sinta, H. D. (2019). The determinant factors of development Batik cluster business: Lesson from Pekalongan, Indonesia. Journal of Asian Finance, Economics and Business, 6(4), 227-233. https://doi.org/10.13106/jafeb.2019.vol6.no4.227. 
Teo, T. S. H., \& Pian, Y. (2003). A contingency perspective on Internet adoption and competitive advantage. European Journal of Information Systems, 12(2), 78-92. https://doi.org/10.1057/ palgrave.ejis. 3000448

Ward, T. B. (2004). Cognition, creativity, and entrepreneurship. Journal of Business Venturing, 19(2), 173-188. https://doi. org/10.1016/S0883-9026(03)00005-3
Wardana, L. W., Handayati, P., Narmaditya, B. S., Wibowo, A., Patma, T. S., \& Suprajan, S. E. (2020). Determinant factors of young people in preparing for entrepreneurship: Lesson from Indonesia. Journal of Asian Finance, Economics and Business, 7(8), 555-566. https://doi.org/10.13106/jafeb.2020.vol7.no8.555

Youndt, M. A., Subramaniam, M., \& Snell, S. A. (2004). Intellectual capital profiles: An examination of investments and returns. Journal of Management Studies, 41(2), 335-361. https://doi. org/10.1111/j.1467-6486.2004.00435.x 